\title{
Attitudes Regarding the Market Economy in Urban China
}

\author{
Ming Tsui ${ }^{1}$ Xiao $\mathrm{Li}^{2}$ \\ ${ }^{1}$ Department of Sociology and Anthropology, Millsaps College, Jackson, USA \\ ${ }^{2}$ School of Social Work, University of Alabama, Tuscaloosa, USA \\ Email: tsuim@millsaps.edu
}

Received December $8^{\text {th }}, 2011$; revised January $9^{\text {th }}, 2012$; accepted February $18^{\text {th }}, 2012$

\begin{abstract}
Compared with only thirty-five years ago, today's China is a different country. As recently as the early 1980s, despite universal poverty, there were universal, life-time employment, cheap work-place-provided housing, national healthcare, and free college education. For those who were born under communism, attitudes toward capitalism were largely negative and large disparities in income and wealth were seen as immoral and unjust. Today the state no longer assigns jobs to those who have completed their education and urban life-time employment and national healthcare are long gone. While there have been stunning improvements in living conditions, the rapid increases in housing prices, coupled with increasing unemployment and a disappearance of job security and national health care, have made ordinary people vulnerable. Because China has become one of the most unequal societies in the world in terms of income and wealth, there is also a sense of discontent among many of its citizens. Using a 2006 national survey, we explore how these changes have affected the public attitudes toward economic reform and communist rule. To our surprise, we found general agreement across different generation, education, and income-mobility groups as regards market economy, the legitimacy of profit-making and income inequality, the role and authority of the government, and the causes of poverty and inequality. The differences among generation, education, and income groups are largely in degree. We suggest that the lack of generation, income, and education differences on attitudes may be due to material benefits brought by the market economy and high economic growth.
\end{abstract}

Keywords: Public Opinion; Economic Reform; Urban China

\section{Introduction}

Compared with only thirty-five years ago, today's China is a different country. As recently as the early 1980s, despite a universally low living standard and the fact that most ordinary Chinese were poor according to western standards, there were universal, life-time employment, cheap work-place-provided housing, national healthcare, and free college education. The Communist Party denounced the capitalist system as evil, and the Chinese people were told repeatedly that a free-market economy means exploitation and oppression of the masses. As a result, for those who were born under communism, attitudes toward capitalism were largely negative and large disparities in income and wealth were seen as immoral and unjust (Barboza, 2010; Mastel, 1997; Whyte \& Parish, 1984).

Today the state no longer assigns jobs to those who have completed their education and urban life-time employment and national healthcare are long gone. While there have been stunning improvements in living conditions, the rapid increases in housing prices, coupled with increasing unemployment and a disappearance of job security and national health care, have made ordinary people vulnerable. Even though most urban residents are several times richer than 35 years ago, there is a wide-spread sense of insecurity caused by the disappearance of the government-provided safety net. Because China has become one of the most unequal societies in the world in terms of income and wealth, there is also a sense of discontent among many of its citizens (Eckholm, 2007; Kahn \& Barboza, 2007; Mastel, 1997).

How have these changes affected the public attitudes toward economic reform and communist rule? What are people's views on capitalism and income inequality? Are there inter-generational differences in attitudes toward these issues? Do income and education levels affect people's attitudes? These are the main questions for this study.

In a 2006 national survey conducted by the Remin University of China ("2006 Comprehensive National Survey", 2006), there were questions about employment, working/living conditions, family life, and personal opinions on various social, economic, and political issues. While the data are not sufficient to provide us with complete answers to our questions, the responses nevertheless offer valuable clues. The survey was the first, largescale national survey that included such politically sensitive questions and so far there have been no English-language publications using this information. In this paper, we present a preliminary analysis of findings regarding urbanities' opinions on the market economy, specifically the legitimacy of profitmaking and income inequality, government regulation over private companies, and reasons for poverty.

\section{Data and Methods}

We use data from the 2006 survey, which was designed and carried out by the Department of Sociology at Remin University of China (a leading university in China in social sciences) on behalf of the Chinese Academy of Social Sciences. The survey used a stratified random sample of more than 10,000 urban and rural households. Within each household, one person was randomly selected for an interview. The interviews were carried out from September to October of 2006, using trained 
teams with specific guidelines regarding interview format and procedures.

The interviews were conducted individually, face to face. An investigator went to the interviewee's residence, read a series of questions to be answered and statements to be rated, and recorded all responses. The interview was between the investigator and interviewee only. If possible, other family members were asked to leave the room while the interviews were being conducted. All together, 10,151 interviews were conducted, more than half with urban residents.

Because the employment situation before, and the effects of, the market reform are very different for urban and rural residents, we decided to focus our analysis only on urban residents. After eliminating cases with missing information, we had available responses from 5200 urban residents. The age of the respondents ranged from 18 to 70 . For dependent variables, we selected the following 12 statements concerning social, economic, and political issues:

1) Society will not progress if companies do not seek profit.

2) Increasing disparity in income makes people work harder.

3) The poor are poor because they do not have sufficient education.

4) The poor are poor because they do not want to work.

5) Bad public policies are an important cause of poverty.

6) Government should tax the rich more in order to assist the poor.

7) As long as there is economic growth and stability, there is no need to promote democracy.

8) You can not go wrong if you listen to the government.

9) Companies have profited a great deal from their employees' labor.

10) Government should impose more regulations on private companies.

11) Decision-making should be left to experts or people with training and knowledge.

12) Experts and intellectuals tend to have higher morals than ordinary people.

The rating scale for each of these statements was "strongly disagree", "disagree", "agree", "strongly agree", and "no answer". We decided to exclude the no-answer response because of its ambiguity. We also decided to combine "strongly dis- agree" with "disagree" (re-labeled "disagree") and "agree" with "strongly agree" (re-labeled "agree"). We treat age, income mobility and education as independent variables. Because urban economic reform started in 1980, we divided the respondents into two generation/age groups, those who were born before 1980 ( $\geq 26$ in 2006) and those who were born in 1980 or later $(\leq 25)$. For income mobility, we used the question "compared with 3 years ago, how has your income changed?" The four possible choices were "increased", "stayed the same", "decreased", and "hard to say". For education, we combined all respondents without college education into one group and those with at least some college into the second group. We use these large groupings because due to a 9-year compulsory education system implemented in the late 1950s, almost all urban residents have at least an elementary-school level of education.

\section{Findings and Discussion}

Table 1 reveals a complex picture as regards respondents' opinion on the market economy, the role of the government in regulating the private sector and government responsibility to assist the poor. In general, urban residents in China support a free market economy and see profit-making in the private sector and income inequality as not only legitimate, but also beneficial for social progress: 77 percent respondents agreed with the statement that "society will not progress if companies do not seek profit," and 60 percent agreed that increasing income disparity will make people work harder. At the same time, individual failure in the market economy was blamed largely on a lack of education rather than a lack of individual effort. Moreover, more than three-fourth of the respondents believed that "bad public policies are an important cause of poverty" and an overwhelming majority agreed that that the rich should be taxed more in order to help the poor and that the government should impose more regulations on the private companies.

The survey found conflicting sentiment toward democracy and the one-party, communist rule. On the one hand, 61 percent of the respondents agreed with the statement that "you can not go wrong if you listen to the government;" on the other hand, 61 percent of the respondents believed that democracy should be promoted even if the economy continues to grow. Eighty-four

Table 1.

Levels of agreement with the 12 statements used in the present study.

\begin{tabular}{lllll}
\hline Statement & Total N & $\%$ agree & $\%$ disagree & $\mathrm{X}^{2}$ \\
\hline Society will not progress if companies do not seek profit. & 5005 & 77.3 & 22.7 & $1491.550^{* * *}$ \\
Increasing disparity in income makes people work harder. & 4972 & 59.7 & 40.3 & $187.682^{* * *}$ \\
The poor are poor because they do not have sufficient education. & 5080 & 60.8 & 39.2 & $238.189^{* * *}$ \\
The poor are poor because they do not want to work. & 5100 & 31.2 & 68.8 & $719.815^{* * *}$ \\
Bad public policies are an important cause of poverty. & 4926 & 77.9 & 22.1 & $1530.758^{* * *}$ \\
Government should tax the rich more in order to assist the poor. & 5005 & 80.6 & 19.4 & $1872.072^{* * *}$ \\
As long as there is economic growth and stability, there is no need to promote democracy. & 4790 & 39.3 & 60.7 & $218.055^{* * *}$ \\
You can not go wrong if you listen to the government. & 4819 & 60.9 & 39.1 & $228.346^{* * *}$ \\
Companies profited a great deal from their employees' labor. & 5054 & 84.1 & 15.9 & $2352.336^{* * *}$ \\
Government should impose more regulations on private companies. & 4937 & 83.4 & 16.6 & $2204.456^{* * *}$ \\
Decision-making should be left to experts or people with training and knowledge. & 4925 & 52.3 & 47.7 & $10.097^{* * *}$ \\
Experts and intellectuals tend to have higher morals than ordinary people. & 5030 & 50.1 & 49.9 & .013 \\
\hline
\end{tabular}

${ }^{*} p<.05,{ }^{* *} p<.01,{ }^{* * *} p<.001$. 
percent of respondents believed that companies profited a great deal from their employees' labor, indicating a sense of injustice felt by these respondents about the current economic systems and labor relations. However, fifty percent of respondents did not seem to believe that equal participation in decision-making is wise or necessary.

Table 2 divides the respondents into two age groups, those who were born before 1980 (aged 26 or older in 2006) and those who were born in or after 1980. The Chinese economic reform started in urban areas in the early 1980s. Since then there has been rapid shift from a state-controlled economy to a free market economy and uninterrupted economic growth. Those who were born in 1980 or after have had almost no personal experience with the socialist economy. For them, a market economy is the norm. Unlike the older generation whose jobs had been assigned by the state, this generation always has had to find its own employment. For them, life-time employment and cradle-to-grave security are not even memories. While there is currently more uncertainty regarding employment and general social security, the market economy has brought this generation material resources and higher living standards than the older generation had ever imagined (Bradsher, 2010; "Chinese takeovers", 2010; "Dating games", 2010; Gross, 2010; Miller, 2010). With increasing access to Western media and increasing freedom for international travel, this younger generation is more familiar than the older generation with notions of democracy and individual rights. Given these facts, we believed that this younger cohort would show stronger support for democracy and a market economy, have stronger beliefs in laisser-faire on social and economic issues, and have strong negative views toward government control and regulation. The survey findings really surprised us. As can be seen in Table 2, on most issues, there was general agreement between the two generational groups and the intergenerational differences in opinions were largely a matter of degree, rather than opposing views. For example, a majority of both generations agreed with the statements regarding reasons for poverty and government assistance to the poor; however, compared to their older counterparts, the younger generation was somewhat less sympathetic toward the poor and less supportive for the idea of taxing the rich to assist poor. A similar pattern was found in the responses regarding government regulation on private companies, where the younger generation was somewhat more conservative than their older counterparts. However, on the statement "as long as there are economic growth and stability, there is no need to promote democracy", the younger group was more liberal than the older group. While a majority of both generations agreed with the statement, "you cannot go wrong if you listen to the government", the proportion within the younger group was much smaller than that of the older group. Additionally, the younger generation seemed to be somewhat more hesitant than the older generation to want leave decision-making to the experts.

Since age-related experience is only one factor that may influence opinions about social, economic, and political issues, we decided to explore relationships between income mobility and opinions on these statements. Respondents were divided into subgroups on the basis of their responses to the income question (see Table 3). Thirty-six percent of urban Chinese have seen their income increase in three years time, 42 percent have seen no change in income, and only 15 percent experienced an income decline. However, regardless of the changes in their personal income, all groups share similar views toward the market economy, the legitimacy of income inequality, the role of the government, and beliefs in the causes of poverty. For example, there was majority agreement across all income groups that "society will not progress if companies do not seek profit" and "increasing disparity in income makes people work harder," although those who experienced an income decline were less likely to agree than did those with income increase. At the same time, those who had benefitted from the market economy were no less likely than those who had not economically benefitted to agree with the statements that "government should tax the rich more in order to help the poor" and "government should impose more regulations on private companies." A majority of respondents in all income mobility groups expressed their trust in the Chinese government, although interestingly, those who experienced upwardly mobility were less

Table 2.

Responses to statements as a function of generation.

\begin{tabular}{|c|c|c|c|c|c|}
\hline \multirow{2}{*}{ Statement } & \multicolumn{2}{|c|}{26 or Older } & \multicolumn{2}{|c|}{ Younger than 26} & \multirow{2}{*}{$X^{2}$} \\
\hline & Total N & $\%$ agree & Total N & $\%$ agree & \\
\hline Society will not progress if companies do not seek profit. & 4233 & 77.2 & 772 & 78.2 & .436 \\
\hline Increasing disparity in income makes people work harder. & 4205 & 59.9 & 767 & 58.5 & .520 \\
\hline The poor are poor because they do not have sufficient education. & 4306 & 60.9 & 774 & 60.5 & .050 \\
\hline The poor are poor because they do not want to work. & 4321 & 30.6 & 779 & 34.4 & $.350^{*}$ \\
\hline Bad public policies are an important cause of poverty & 4176 & 78.2 & 750 & 75.9 & 2.066 \\
\hline Government should tax the rich more in order to assist the poor. & 4243 & 81.1 & 762 & 77.4 & $.705^{*}$ \\
\hline As long as there is economic growth and stability, there is no need to promote democracy. & 4047 & 40.3 & 743 & 33.9 & $10.808^{* * *}$ \\
\hline You can not go wrong if you listen to the government. & 4080 & 61.8 & 739 & 55.8 & $9.657^{* *}$ \\
\hline Companies have profited a great deal from their employees' labor. & 4281 & 83.9 & 773 & 85.1 & .698 \\
\hline Government should impose more regulations on private companies. & 4188 & 83.9 & 749 & 80.5 & $5.390^{*}$ \\
\hline Decision making should be left to experts or people with training and knowledge. & 4169 & 53.6 & 756 & 45.1 & $18.342^{* * *}$ \\
\hline Experts and intellectuals tend to have higher morals than ordinary people. & 4260 & 50.3 & 770 & 48.7 & .691 \\
\hline
\end{tabular}

${ }^{*} p<.05,{ }^{* *} p<.01,{ }^{* * *} p<.001$. 
Table 3.

Responses to statements as a function of income mobility.

\begin{tabular}{|c|c|c|c|c|}
\hline Statement & Income & Total N & $\%$ Agree & $\mathrm{X}^{2}$ \\
\hline \multirow{4}{*}{$\begin{array}{l}\text { Society will not progress if companies } \\
\text { do not seek profit. }\end{array}$} & Increased & 1810 & 79.9 & \\
\hline & The same & 2109 & 76.2 & \\
\hline & Decreased & 755 & 73.1 & \\
\hline & Hard to say & 331 & 79.5 & $16.986^{* * *}$ \\
\hline \multirow[t]{4}{*}{ Increasing disparity in income makes people work harder. } & Increased & 1798 & 62.6 & \\
\hline & The same & 2086 & 57.6 & \\
\hline & Decreased & 761 & 58.0 & \\
\hline & Hard to say & 327 & 58.0 & $11.291^{* *}$ \\
\hline \multirow{4}{*}{$\begin{array}{l}\text { The poor are poor because they do not have sufficient } \\
\text { education. }\end{array}$} & Increased & 1839 & 61.7 & \\
\hline & The same & 2132 & 60.8 & \\
\hline & Decreased & 770 & 61.4 & \\
\hline & Hard to say & 342 & 55.0 & 5.642 \\
\hline \multirow[t]{4}{*}{ The poor are poor because they do not want to work. } & Increased & 1841 & 33.4 & \\
\hline & The same & 2141 & 30.2 & \\
\hline & Decreased & 773 & 27.2 & \\
\hline & Hard to say & 345 & 33.0 & $12.855^{* *}$ \\
\hline \multirow[t]{4}{*}{ Bad public policies are an important cause of poverty. } & Increased & 1771 & 76.4 & \\
\hline & The same & 2070 & 76.9 & \\
\hline & Decreased & 758 & 83.0 & \\
\hline & Hard to say & 320 & 80.3 & $15.966^{* * *}$ \\
\hline \multirow[t]{4}{*}{ Government should tax the rich more in order to help the poor. } & Increased & 1808 & 79.6 & \\
\hline & The same & 2103 & 80.6 & \\
\hline & Decreased & 767 & 83.2 & \\
\hline & Hard to say & 324 & 80.1 & 4.492 \\
\hline \multirow{4}{*}{$\begin{array}{l}\text { As long as there is economic growth and stability, there is no } \\
\text { need for democracy. }\end{array}$} & Increased & 1747 & 40.0 & \\
\hline & The same & 2012 & 38.9 & \\
\hline & Decreased & 728 & 39.8 & \\
\hline & Hard to say & 303 & 36.6 & 1.646 \\
\hline \multirow[t]{4}{*}{ You can not go wrong if you listen to the government. } & Increased & 1770 & 57.7 & \\
\hline & The same & 2019 & 62.7 & \\
\hline & Decreased & 722 & 64.0 & \\
\hline & Hard to say & 308 & 60.4 & $13.225^{* *}$ \\
\hline \multirow{4}{*}{$\begin{array}{l}\text { Companies have profited a great deal from their employees' } \\
\text { labor. }\end{array}$} & Increased & 1831 & 82.7 & \\
\hline & The same & 2126 & 83.1 & \\
\hline & Decreased & 765 & 87.8 & \\
\hline & Hard to say & 299 & 90.1 & $21.279^{* * *}$ \\
\hline \multirow{4}{*}{$\begin{array}{l}\text { Government should impose more regulations on private } \\
\text { companies. }\end{array}$} & Increased & 1782 & 82.5 & \\
\hline & The same & 2086 & 83.7 & \\
\hline & Decreased & 756 & 84.7 & \\
\hline & Hard to say & 313 & 83.7 & 1.915 \\
\hline \multirow{4}{*}{$\begin{array}{l}\text { Decision making should be left to experts or people with } \\
\text { training and knowledge. }\end{array}$} & Increased & 1782 & 53.4 & \\
\hline & The same & 2075 & 52.3 & \\
\hline & Decreased & 754 & 53.3 & \\
\hline & Hard to say & 314 & 43.0 & $12.024^{* *}$ \\
\hline \multirow{4}{*}{$\begin{array}{l}\text { Experts and intellectuals tend to have higher morals than } \\
\text { ordinary people. }\end{array}$} & Increased & 1806 & 51.6 & \\
\hline & The same & 2210 & 50.1 & \\
\hline & Decreased & 768 & 48.0 & \\
\hline & Hard to say & 336 & 50.1 & 4.627 \\
\hline
\end{tabular}

${ }^{*} p<.05,{ }^{* *} p<.01,{ }^{* * *} p<.001$.

likely to agree with the statement that "you can not go wrong if you listen to the government". On the whole, these urban residents seemed to give their government a lot of credit for economic development and for improvement in their income. At the same time, the majority wanted government roles limited to taxing the rich in order to help the poor and to preventing market excess and exploitation. While an overwhelming majority across all income groups believed that companies profited a great deal from their employees' labor, reflecting a sense of dissatisfaction toward the current system, only 61 percent expressed a desire for political change and democracy.

To further explore why respondents replied the way they did, we included the factor of education level in our analysis (see Table 4). In 2006, only 21.6 percent of respondents had at least some college education. As regards opinions on a majority of social, economic, and political issues, once again, we found 
Table 4.

Response to statements as a function of education levels.

\begin{tabular}{|c|c|c|c|c|}
\hline Statement & Education & Total N & $\%$ Agree & $\mathrm{X}^{2}$ \\
\hline \multirow{2}{*}{$\begin{array}{l}\text { Society will not progress if } \\
\text { companies do not seek profit. }\end{array}$} & No college & 3904 & 76.9 & \\
\hline & Some college or above & 1094 & 78.8 & 1.755 \\
\hline \multirow{2}{*}{$\begin{array}{l}\text { Increasing disparity in incomes } \\
\text { makes people work harder. }\end{array}$} & No college & 3878 & 59.7 & \\
\hline & Some college or above & 1087 & 59.9 & .013 \\
\hline \multirow{2}{*}{$\begin{array}{l}\text { The poor are poor because they } \\
\text { do not have sufficient education. }\end{array}$} & No college & 3978 & 60.4 & \\
\hline & Some college or above & 1095 & 62.4 & 1.359 \\
\hline \multirow{2}{*}{$\begin{array}{l}\text { The poor are poor because they } \\
\text { do not want to work. }\end{array}$} & No college & 3987 & 31.7 & \\
\hline & Some college or above & 1106 & 29.1 & 2.863 \\
\hline \multirow{2}{*}{$\begin{array}{l}\text { Bad public policies are an } \\
\text { important cause of poverty. }\end{array}$} & No college & 3931 & 78.9 & \\
\hline & Some college or above & 1088 & 74.4 & $9.799^{* * *}$ \\
\hline \multirow{2}{*}{$\begin{array}{l}\text { Government should tax the rich } \\
\text { more in order to help the poor. }\end{array}$} & No college & 3915 & 81.3 & \\
\hline & Some college or above & 1083 & 77.9 & $6.159^{*}$ \\
\hline \multirow{2}{*}{$\begin{array}{l}\text { As long as there is economic growth and } \\
\text { stability, there is no need for democracy. }\end{array}$} & No college & 3718 & 41.3 & \\
\hline & Some college or above & 1065 & 32.8 & $24.992^{* * *}$ \\
\hline \multirow{2}{*}{$\begin{array}{l}\text { You can not go wrong if you } \\
\text { listen to the government. }\end{array}$} & No college & 3755 & 62.7 & \\
\hline & Some college or above & 1057 & 54.6 & $22.736^{* * *}$ \\
\hline \multirow{2}{*}{$\begin{array}{l}\text { Companies have profited a great } \\
\text { deal from their employees' labor. }\end{array}$} & No college & 3945 & 83.9 & \\
\hline & Some college or above & 1102 & 84.9 & 722.00 \\
\hline \multirow{2}{*}{$\begin{array}{l}\text { Government should impose more } \\
\text { regulations on private companies. }\end{array}$} & No college & 3852 & 83.5 & \\
\hline & Some college or above & 1080 & 83.1 & .129 \\
\hline \multirow{2}{*}{$\begin{array}{l}\text { Decision making should be left to experts or } \\
\text { people with training and knowledge. }\end{array}$} & No college & 3838 & 54.0 & \\
\hline & Some college or above & 1080 & 46.3 & $19.844^{* * *}$ \\
\hline \multirow{2}{*}{$\begin{array}{l}\text { Experts and intellectuals tend to have higher } \\
\text { morals than ordinary people. }\end{array}$} & No college & 3932 & 51.5 & \\
\hline & Some college or above & 1091 & 45.0 & $14.528^{* * *}$ \\
\hline
\end{tabular}

strong agreement between the two education groups. The pattern of the responses is similar to those we found in our analysis on generation and income mobility. An interesting, but expected, finding here is the answers to issues on democracy and trust of government where the college-educated tended to be more liberal in their opinions than those without a college education. The responses to the statements concerning decisionmaking are also interesting. Unlike the responses to most statements, the responses here are of opposite direction between the two education groups. Among those with no college education, more than half agreed with the statement that decision-making should be left to experts, while less than half of the respondents with college education agreed with the statement. The statement "experts and intellectuals tend to have higher morals than ordinary people" elicited similar patterns of response. These findings seem to suggest that education still commanded respect in China and educated people were more likely to be trusted in decision-making by their less-educated counterparts. At the same time, the educated themselves were less confident.

\section{Summary and Conclusion}

To our surprise, we found general agreement across different generation, education, and income-mobility groups as regards market economy, the legitimacy of profit-making and income inequality, the role and authority of the government, and the causes of poverty and inequality. The differences among generation, education, and income groups are largely in degree. The findings on attitudes and income mobility are the most surprising because we had expected a strong sense of dissatis- faction with market reform among those who did not see income growth. We suggest that the lack of generation, income, and education differences on attitudes may be due to material benefits brought by the market economy and high economic growth. Since the early 1980s, the Chinese economy has grown consistently at about 10 percent GDP per year and personal income and the living standards have doubled every 10 years (Miller, 2010). While individual Chinese may experience different degrees of improvement in their material life and upward mobility, very few have been completely left out of this economic development and have not seen improvement in their material lives. Because the changes occurred within a generation, they offer people a clear historical comparison between the old socialist economy and the current market economy; and such comparison makes the current economy look more attractive. This comparison may explain why there was strong support for the market economy among those whose income had increased and those whose incomes had not. It must be uplifting for many Chinese to witness their country becoming, in a short span of 30 years, the $2^{\text {nd }}$ largest economy in the world (from a poor country with 60 percent of its population living in abject poverty.) Under these circumstances, individuals are more hopeful and optimistic about their future and the future of their children. Those who have not done well financially can blame lack of education or lack of luck for their failure; and at the same time, hope that with better education, their children will do better than themselves. This may explain why there is no objection to profit making even among those who did not fare well in terms of income. Moreover, the rapid economic growth and improvement in living standards, coupled with the failure 
of, and chaos after, the 1989 democracy movement, may lead many Chinese to prefer economic stability over democracy/ political change. Finally, a strong, shared support for government to tax the rich in order to help the poor and for more government regulation seem to reflect the influence of a socialist tradition.

\section{REFERENCES}

Barboza, D. (2010). Changes in China could raise prices worldwide. The New York Times, 7 June 2010. URL.

http://www.nytimes.com/2010/06/08/business/global/08wages.html

Bradsher, K. (2010). For auto industry, questions about Beijing's road ahead. The New York Times, 29 December 2010. URL.

http://www.nytimes.com/2010/12/30/business/global/30auto.html

Chinese Takeovers. (2010). The economist. 13-19 November 2010, 81-83.

Dating Games. (2010). The economist. 18-31 December 2010, 145.

Eckholm, E. (2007). Worker's rights are suffering in China as manu- facturing goes capitalist. The New York Times, 22, August 2001. URL. http://www.nytimes.com/2001/08/22/world/workers-rights-are-suffer ing-in-china-as-manufacturing-goes-capitalist.html

Gross, M. (2010). Lost in China. The New York Times, 26 December 2010. URL. http://travel.nytimes.com/2010/12/26/travel/26chongqing.html

Kahn, J., \& Barboza, D. (2007). As unrest rises, China broadens worker's rights. The New York Times, 30 June 2007. URL.

http://www.nytimes.com/2007/06/30/world/asia/30china.html

Mastel, G. (1997). The rise of the Chinese economy: The middle kingdom emerges. Armonk, NY: M.E. Sharpe.

Miller, K. (2010). Coping with China's financial power. Foreign Affairs, July/August 2010, 96-110. URL.

http://www.foreignaffairs.com/articles/66466/ken-miller/coping-with -chinas-financial-power

Remin University of China. (2006). Comprehensive National Survey of the Livelihood of Chinese Urban and Rural Residents. Beijing: Remin University of China.

Whyte, M., \& Parish, W. (1984). Urban life in contemporary China. Chicago: University of Chicago Press. 